\title{
PENERAPAN MODEL PEMBELAJARAN DISCOVERY LEARNING UNTUK MENINGKATKAN HASIL BELAJAR SISWA PADA TEMA DAERAH TEMPAT TINGGALKU KELAS IV SDN 5 PASIR PUTIH
}

\author{
Endang ${ }^{1)}$, La Anse ${ }^{1)}$, I Ketut Suardika ${ }^{1)}$ \\ 1) Jurusan Pendidikan Guru Sekolah Dasar, \\ FKIP Universitas Halu Oleo
}

Email: endangpgsd010@gmail.com, laanse56@gmail.com, iketutsuardika@uho.ac.id

\begin{abstract}
Abstrak: Penelitian ini bertujuan untuk meningkatkan hasil belajar siswa melalui model pembelajaran discovery learning pada tema daerah tempat tinggalku di Kelas IV SDN 5 Pasir Putih Kabupaten Muna. Metode dalam penelitian ini adalah Penelitian Tindakan Kelas. Subjek dalam penelitian ini adalah guru dan siswa kelas IV SDN 5 Pasir Putih Kabupaten Muna, siswa laki-laki 11 orang dan siswa perempuan 6 orang. Jenis data dalam penelitian ini adalah data kualitatif melalui lembar observasi dan data kuantitatif melalui hasil belajar siswa. Berdasarkan analisis data hasil belajar siswa diperoleh dari siklus I hingga siklus II yang ditunjukkan yakni pada siklus I dengan rata-rata 62,75 yaitu dari 17 orang siswa, yang tuntas sebanyak 7 orang dengan persentase $41,18 \%$ dan yang tidak tuntas sebanyak 10 orang dengan persentase $58,82 \%$. Sedangkan pada siklus II diperoleh peningkatan dengan rata-rata 82,35 yang tuntas sebanyak 15 orang dengan persentase $88,24 \%$ dan yang tidak tuntas sebanyak 2 orang dengan persentase $11,76 \%$. Sehingga dapat disimpulkan bahwa penerapan model pembelajaran discovery learning dapat meningkatkan hasil belajar siswa pada tema Daerah Tempat Tinggalku kelas IV SDN 5 Pasir Putih.
\end{abstract}

Kata Kunci: Penerapan model pembelajaran; Discovery learning; dan Hasil belajar

\section{APPLICATION OF DISCOVERY LEARNING LEARNING MODELS TO IMPROVE STUDENT LEARNING OUTCOMES IN THE THEMES OF CLASS IV STAYINGS OF SDN 5 PASIR PUTIH}

\begin{abstract}
This research aims to improve student learning outcomes through a discovery learning model on the theme of the area where I live in grade IV SDN 5 Pasir Putih, Muna Regency. The method in this research is Classroom Action Research. The subjects in this research were teachers and fourth grade students of SDN 5 Pasir Putih, Muna Regency, 11 male students and 6 female students. The type of data in this research is qualitative data through observation sheets and quantitative data through student learning outcomes. Based on the analysis of student learning outcomes data obtained from cycle I to cycle II is shown in cycle I with an average of 62.75, namely from 17 students, 7 people completed with a percentage of $41.18 \%$ and completeness of 10 people. incomplete with a percentage of $58.82 \%$. Whereas in cycle II there was an increase with an average of 82.35 who completed as many as 15 people with a percentage of $88.24 \%$ and 2 people who did not complete with a percentage of $11.76 \%$. So it can be concluded that the application of discovery learning models can improve the learning outcomes of fourth grade students of SDN 5 Pasir Putih, Muna Regency.
\end{abstract}

Keywords: Implementation; discovery learning model; learning outcomes 


\section{Pendahuluan}

Kurikulum di Indonesia yang sering mengalami perubahan disebabkan ketidaksesuaian output secara nyata dengan yang diharapkan. Perubahan kurikulum dari KTSP menjadi Kurikulum 2013 menimbulkan berbagai permasalahan di sekolah, selain ketidaksiapan guru dalam menerapkan kurikulum ini ternyata ada permasalahan yeng lebih mendasar yang dialami oleh guru yaitu rendahnya hasil belajar siswa dan kurangnya motivasi siswa saat pembelajaran. Kurikulum 2013 menerapkan pendekatan pembelajaran scientific approach siswa dituntut untuk lebih aktif dan kritis dalam pembejaran di kelas (Kawuri et al. 2019, p. 105-114). Kenyataan di lapangan terutama pembelajaran siswa di Sekolah Dasar perlu menggunakan pendekatan yang lebih berkaitan dengan masalah serta dikaitkan dengan kejadian sehari-hari. Hal ini dimaksudkan agar pemahaman siswa lebih tertanam di otak dan tidak menimbulkan salah konsep akan materi yang sedang dipelajari. Pembelajaran di sekolah terlalu menjejali otak siswa dengan berbagi bahan ajar yang bersifat hafalan tetapi kurang mengarahkan siswa untuk mengembangkan dan membangun karakter serta kemampuan siswa. Penumpukan konsep dan informasi oleh siswa kurang bermanfaat karena materi hanya dikomunikasikan oleh guru satu arah saja. Pemahaman konsep dalam belajar sangat penting, hal ini akan mempengaruhi sikap, keputusan dan cara-cara memecahkan masalah, maka belajar bermakna sangat penting.

Melihat kenyataan yang ada di SDN 5 Pasir Putih masih banyak siswa yang kurang memahami akan materi yang sedang dipelajari, demikian pula masih ada guru yang saat pembelajaran kurang bervariasi dalam menerapkan model pembelajaran. Padahal menurut tuntutan kurikulum 2013 guru hendaknya menggunakan model pembelajaran yang bervariasi disesuaikan dengan materi yang dipelajari. Model pembelajaran menurut kurikulum 2013 antara lain discovery learning, problem based learning, project based learning, inquiry based learning sesuai dengan pendekatan saintifik yaitu 5M (mengamati, menanya, mengumpulkan data, mengasosiasi, mengomunikasikan) (Sofyan \& Komariah, 2016, p. 260-271). Saat pembelajaran berlangsung masih banyak siswa kurang berani bertanya apabila ada materi yang kurang dipahami, siswa kurang berani mengemukakan pendapat, siswa masih ada yang diam saat pembelajaran, siswa kurang merespon tugas yang diberikan guru. Siswa cenderung asik dengan kesibukan sendiri yang mengganggu siswa lain saat pembelajaran berlangsung, yang akhirnya hasil belajar siswa kurang maksimal. Demikian pula saat ulangan harian masih ditemukan siswa yang kurang percaya diri akan kemampuan yang dimiliki karena masih ada siswa yang bertanya pada teman lain saat ulangan berlangsung.

Pembelajaran akan optimal dan bermakna, apabila guru kreatif, inovatif dan selalu berusaha secara terus menerus untuk meningkatkan mutu pembelajaran di kelas. Peningkatan mutu pembelajaran di kelas akan berpengaruh pada mutu pendidikan pada umumnya. Upaya memperbaiki dan meningkatkan mutu pembelajaran di kelas yang dilakukan oleh guru melalui pendekatan atau strategi pembelajaran yang maksimal. Salah satu upaya strategi pembelajaran /dengan melakukan penelitian tindakan kelas. Pelaksanaan Penelitian Tindakan Kelas (Classroom Action Research) dapat dicirikan yakni adanya perencanaan (planing), pelaksanaan tindakan (action, pengamatan (observation), evaluasi (evaluation), dan akhiri dengan kegiatan refleksi (reflection) di setiap siklus pembelajaran, (Narmaditya et al. 2017, p. 1-11).

Berdasarkan hasil observasi penulis di SDN 5 Pasir Putih pada siswa kelas IV, menunjukkan bahwa proses pembelajaran yang dilaksanakan masih bersifat konvensional. Hal ini dikarenakan minat baca siswa rendah baik buku pelajaran atau sumber belajar lain yang menunjang proses belajar mengajar di kelas. Guru lebih aktif dalam proses pembelajaran di kelas sehingga siswa lebih banyak pasif, dengan demikian hasil belajar siswa masih kurang bahkan di bawah kriteria ketuntasan minimal. Kriteria Ketuntasan Minimal (KKM) yang ditetapkan oleh SDN 5 Pasir Putih pada kelas IV yakni sebesar 65. Sesuai hasil observasi bahwa presentase nilai rata-rata ulangan tengah semester (UTS) siswa kelas IV tahun ajaran 2018/2019 rendah yaitu 57,61 dimana presentasenya hanya $35 \%$ yang tuntas dan $65 \%$ yang tidak tuntas dengan kata lain dari jumlah siswa 28 orang hanya terdapat 9 orang yang tuntas (nilai $\mathrm{KKM} \geq 65$ ) dan selebihnya 17 orang siswa yang belum tuntas karena berada di bawah nilai KKM. Rendahnya capain nilai siswa dikarenakan siswa kurang mampu menyelesaikan permasalahan sesuai tahapan-tahapan penyelesaian soal serta minat belajar siswa yang masih rendah. 
Berdasarkan latar belakang tersebut, maka penulis mengambil judul "Penerapan Model Pembelajaran Discovery Learning Untuk Meningkatkan Hasil Belajar Siswa pada Tema Daerah Tempat Tinggalku di Kelas IV SDN 5 Pasir Putih Kabupaten Muna."

\section{Metode Penelitian}

Jenis penelitian ini adalah penelitian tindakan kelas. Penelitian ini dilaksanakan di SDN 5 Pasir Putih yang terletak di Desa Pola, Kecamatan Pasir Putih, Kabupaten Muna pada semester genap tahun ajaran 2019/2020. Subjek dalam penelitian ini adalah guru dan siswa kelas IV SDN 5 Pasir Putih dimana keseluruhan siswa berjumlah 17 orang. Siswa laki-laki sebanyak 11 orang dan siswa perempuan sebanyak 6 orang. Faktor - faktor yang diteliti pada penelitian ini adalah : 1) Melihat aktivitas siswa dalam proses pembelajaran di kelas ketika guru menerapkan model pembelajaran Discovery learning pada tema daerah tempat tinggalku, 2) Melihat kemampuan guru dalam menerapkan model pembelajaran Discovery learning pada tema daerah tempat tinggalku, 3) Melihat hasil belajar siswa dengan menggunakan model pembelajaran Discovery learning pada tema daerah tempat tinggalku diakhir siklus tindakan yang dilakukkan oleh guru dan siswa. Penelitian Tindakan Kelas ini dilaksanakan dalam dua siklus.

Adapun prosedur penelitian tindakan ini menurut Nichen, dkk (2018, p. 72) rancangan Penelitian Tindakan Kelas terdiri atas empat rangkaian kegiatan yang dilakukan dalam siklus berulang yaitu (1) Planning (perencanaan), (2) Action (tindakan), (3) Observasi (pengamatan), (4) Reflection (refleksi). Jenis data yaitu data kualitatif dan data kuantitatif. Data kualitatif diperoleh melalui observasi, menggunakan lembar observasi sedangkan data kuantitatif diperoleh melalui tes pada setiap akhir siklus tindakan. Data kualitatif dianalisis secara deskriptif kualitatif data yang dideskripsikan berupa data hasil observasi sedangkan data kuantitatif dianalisis secara deskrptif kuantitatif berdasarkan hasil tes.

\section{Hasil Penelitian}

\section{Aktivitas Guru}

Aktivitas guru dalam penelitian ini adalah mengajar, dimana proses mengajar disesuaikan dengan langkah-langkah model pembelajaran yang sedang diteliti. Menurut (Suprijiono, 2017, p. 13) mengajar adalah aktivitas guru dalam menyediakan fasilitas belajar bagi peserta didiknya untuk mempelajarinya. Berdasarkan hasil observasi dan evaluasi pada aktivitas mengajar guru yang dilakukan peneliti dapat dilihat pada Tabel 1 berikut :

Tabel 1.Rekapitulasi Aktivitas Guru Siklus I dan Siklus II

\begin{tabular}{|c|c|c|c|c|c|}
\hline \multirow{2}{*}{ No. } & \multirow{2}{*}{ Aspek yang diamati } & \multicolumn{2}{|c|}{ Siklus I } & \multicolumn{2}{|c|}{ Siklus II } \\
\hline & & P1 & $\mathrm{P} 2$ & P1 & $\mathrm{P} 2$ \\
\hline 1. & $\begin{array}{l}\text { Guru menghadapkan siswa pada permasalahan yang menimbulkan rasa } \\
\text { ingin tahu dan timbul keinginan untuk menyelidiki sendiri. }\end{array}$ & 0 & 1 & 1 & 1 \\
\hline 2. & $\begin{array}{l}\text { Guru memberi kesempatan kepada siswa untuk mengidentifikasi } \\
\text { sebanyak mungkin masalah yang relevan dengan bahan pelajaran. }\end{array}$ & 0 & 0 & 1 & 1 \\
\hline 3. & $\begin{array}{l}\text { Guru membimbing siswa untuk merumuskan hipotesis (jawaban } \\
\text { sementara) }\end{array}$ & 1 & 1 & 1 & 1 \\
\hline 4. & $\begin{array}{l}\text { Guru meminta siswa mengumpulkan berbagai informasi yang relevan } \\
\text { dengan bahan pelajaran melalui LKS. }\end{array}$ & 1 & 1 & 1 & 1 \\
\hline 5. & $\begin{array}{l}\text { Guru memberikan kesempatan kepada siswa untuk mengolah data dan } \\
\text { informasi yang telah diperoleh. }\end{array}$ & 0 & 1 & 1 & 1 \\
\hline 6. & $\begin{array}{l}\text { Guru menyuruh siswa untuk membuktikan penemuan suatu konsep, } \\
\text { teori, aturan atau pemahaman melalui contoh-contoh }\end{array}$ & 1 & 1 & 1 & 1 \\
\hline 7. & $\begin{array}{l}\text { Guru meminta siswa menarik sebuah kesimpulan yang dapat dijadikan } \\
\text { prinsip umum dan berlaku untuk semua kejadian atau masalah yang } \\
\text { sama. }\end{array}$ & 0 & 1 & 1 & 1 \\
\hline \multicolumn{2}{|r|}{ Jumlah } & 3 & 6 & 7 & 7 \\
\hline \multicolumn{2}{|c|}{ Rata-Rata } & \multicolumn{2}{|c|}{4,5} & \multicolumn{2}{|c|}{7} \\
\hline \multicolumn{2}{|c|}{ Presentase } & \multicolumn{2}{|c|}{$64,28 \%$} & \multicolumn{2}{|c|}{$100 \%$} \\
\hline
\end{tabular}

Keterangan: $1=$ Terlaksana, $0=$ Tidak Terlaksana 
Hasil observasi aktivitas mengajar guru pada siklus I masih ada kelemahan atau aspekaspek yang belum dilakukan oleh guru seperti: a) guru tidak menghadapkan siswa pada permasalahan yang menimbulkan keingintahuan siswa, b) guru tidak memberikan kesempatan kepada siswa untuk mengolah data yang diperoleh, c) guru tidak meminta siswa untuk menarik sebuah kesimpulan. Sedangkan hasil aktivitas mengajar guru pada siklus II telah mengalami peningkatan dari siklus I, hal ini dapat dilihat dari keseluruhan aspek telah terlaksana sesuai dengan langkah-langkah model pembelajaran discovery learning.

\section{Aktivitas Siswa}

Aktivitas siswa yang diteliti dalam penelitian ini adalah bagaimana siswa mengikuti proses pembelajaran berlansung atau bagaimana siswa belajar, menurut Cronbach (Suprijiono, 2017, p. 2) menjelaskan bahwa "Learning is shown by a change in behavior as a result of experience (Belajar adalah perubahan perilaku sebagai hasil dari pengalaman. Berdasarkan hasil observasi dan evaluasi pada aktivitas pembelajaran siswa yang dilakukan peneliti dapat dilihat pada Tabel 2 berikut :

Tabel 2. RekapitulasiAktivitas Siswa Siklus I dan Siklus II

\begin{tabular}{llcccc} 
No. & Aspek yang diamati & \multicolumn{2}{c}{ Siklus I } & \multicolumn{2}{c}{ Siklus II } \\
\cline { 3 - 6 } & & P1 & P2 & P1 & P2 \\
\hline 1. & Siswa mendengarkan uraian yang memuat persoalan & 0 & 1 & 1 & 1 \\
\hline 2. & Siswa mengidentifikasi berbagai permasalahan dalam LKS & 0 & 0 & 1 & 1 \\
\hline 3. & Siswa merumuskan hipotesis jawaban & 1 & 1 & 1 & 1 \\
\hline 4. & $\begin{array}{l}\text { Siswa mengumpulkan berbagai informasi yang relevan dari } \\
\text { buku sisiwa }\end{array}$ & 1 & 0 & 1 & 1 \\
\hline 5. & Siswa melakukan diskusi kelompok & 0 & 1 & 1 & 1 \\
\hline 6. & $\begin{array}{l}\text { Siswa melakukan presentasi hasil diskusi kelompok di depan } \\
\text { kelas }\end{array}$ & 1 & 1 & 1 & 1 \\
\hline 7. & Siswa menarik sebuah kesimpulan & 0 & 1 & 1 & 1 \\
\hline & Jumlah & 3 & 5 & 7 & 7 \\
\hline & Rata-Rata & \multicolumn{2}{c}{4} & & 7 \\
\hline & Presentase & $57,14 \%$ & & $100 \%$ \\
\hline
\end{tabular}

Keterangan: 1 = Terlaksana, $0=$ Tidak Terlaksana

Pada siklus I ada beberapa kelemahan atau aspek-aspek yang belum dilakukan oleh siswa dalam proses pembelajaran, yaitu: a) siswa tidak mendengarkan uraian persoalan yang disajikan oleh guru, b) mengidentifikasi berbagai permasalahan dalam LKS, c) siswa tidak menarik sebuah kesimpulan pada akhir pembelajaran. Sedangkan pada siklus II telah mengalami peningkatan dari siklus I, hal ini dapat dilihat dari keseluruhan aspek telah terlaksana sesuai dengan langkah-langkah model pembelajaran discovery learning.

\section{Hasil Belajar Siswa}

Hasil analisis penelitian pada siklus I terdapat 7 orang siswa yang telah mencapai KKM dengan nilai $\geq 65$ dengan ketuntasan sebesar $41,18 \%$ dan 10 orang siswa yang tidak tuntas dengan persentase sebesar 58,82\% dengan nilai rata-rata 62,75. Pada siklus II terdapat 15 orang siswa telah mencapai KKM dengan nilai $\geq 65$ dengan persentase ketuntasan sebesar $88,24 \%$ dan yang tidak tuntas sebanyak 2 orang dengan persentase sebesar 11,75\% dengan nilai rata-rata 82,35. 
Tabel 3. Daftar Nilai Hasil Belajar Siswa Siklus I dan Siklus II

\begin{tabular}{lcc}
\hline \multicolumn{1}{c}{ Pencapaian } & \multicolumn{2}{c}{ Siklus } \\
\cline { 2 - 3 } & $\mathbf{1}$ & $\mathbf{2}$ \\
\hline Jumlah Siswa & 17 Orang & 17 Orang \\
\hline Nilai Tertinggi & 86,67 & 93,33 \\
\hline Nilai Terendah & 46,67 & 60,00 \\
\hline Nilai Rata-Rata & 62,75 & 82,35 \\
\hline \% Tuntas & $41,18 \%$ & $88,24 \%$. \\
\hline \% Tindak Tuntas & $58,82 \%$ & $11,76 \%$ \\
\hline
\end{tabular}

Sumber: dari data hasil

Berdasarkan uraian pada siklus I dan II, menunjukkan bahwa model pembelajaran discovery learning dapat meningkatkan hasil belajar siswa. Hal ini dapat tercapai karena siswa tidak hanya tidak hanya mendengarkan penjelasan guru namun juga berpartisipasi dalam mengumpulkan informasi dari berbagi sumber untuk menyelesaikan masalah yang diberikan. Selain itu juga karena guru mengikuti langkah-langkah model pembelajaran discovery learning dengan tepat dan efisien.

\section{Pembahasan}

1. Aktivitas Guru

Aktivitas guru pada penelitian ini diketahui melalui hasil observasi pada siklus I pertemuan pertama dan kedua membuktikan bahwa guru dalam melaksanakan pembelajaran dengan menerapkan model pembelajaran model discovery learning terdapat beberapa kelemahan, diantaranya: a) guru kurang memaksimalkan penyampaian motivasi kepada siswa, b) guru kurang merangsang siswa untuk mengumpulkan ide dan gagasan dari berbagai informasi dalam LKS yang disediakan, serta guru tidak memberi penguatan kepada siswa dalam mempresentasikan hasil pendapatnya. Hal ini dikarenakan guru belum mampu mengkondisikan kelas dengan baik dan belum menguasai setiap aspek dalam rancangan model pembelajaran discovery learning, sehingga hal ini berpengaruh pada aktivitas belajar siswa. Hal ini sejalan dengan pendapat Slameto (2010, p. 97) bahwa aktivitas dan kreativitas siswa dalam belajar sangat bergantung pada aktivitas dan peran guru dalam mempersiapkan pembelajaran serta mampu untuk melihat segala sesuatu yang terjadi dalam kelas untuk membantu proses perkembangan siswa.

Kelemahan-kelemahan yang temui pada siklus I, kemudian langsung direfleksi dan dilakukan perbaikan pembelajaran untuk dilaksanakan pada siklus selanjutnya yaitu siklus II. Sedangkan pada pelaksanaan tindakan siklus II aktivitas mengajar guru mengalami peningkatan sehingga guru telah mampu mengkondisikan kelas dengan baik serta sudah mampu menguasai rancangan model pembelajaran discovery learning. Grafik kenaikan aktivitas guru dapat dilihat gambar berikut. 


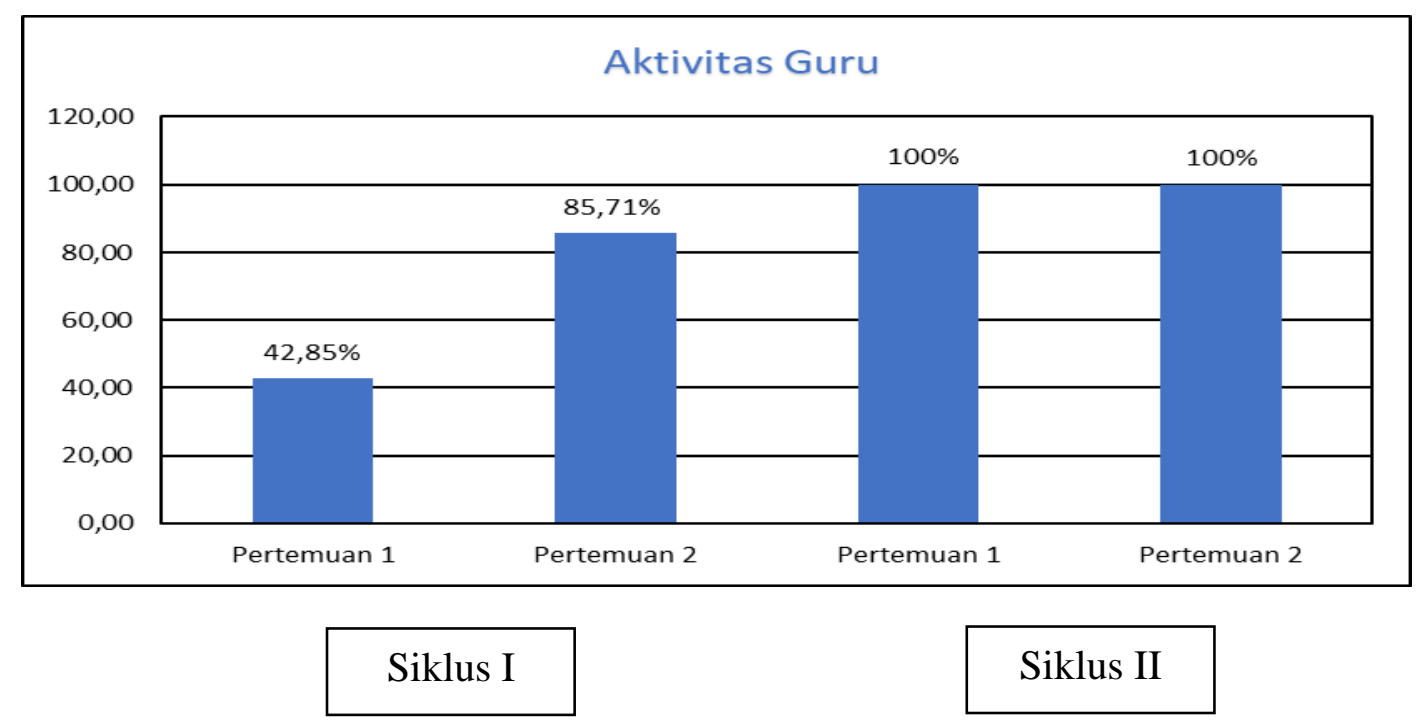

\section{Aktivitas Sisiwa}

Gambar 1. Peningkatan aktivitas guru

Aktivitas siswa dapat dipengaruhi oleh aktivitas guru, apabila guru menjalankan aktivitas dengan baik maka siswa juga pasti beraktivitas dengan baik pula dan apabila aktivitas guru tidak baik maka aktivitas siswa terganggu atau bermasaalah. Dari hasil observasi pada siklus I pertemuan pertama dan kedua, menunjukkan bahwa aktivitas siswa selama proses pelaksanaan pembelajaran masih terdapat beberapa aspek yang masih ditemukan adanya kelemahan seperti; (1) masih ada sebagian siswa cenderung kurang antusias pada saat proses pembelajaran berlangsung, dimana siswa sebagian asik bermain dan menimbulkan keributan, (2) sebagian siswa kurang berani bertanya apabila ada materi yang kurang dipahami, (3) adapula sebagian siswa yang merasa malumalu saat mengemukakan pendapatnya dikarenakan siswa sangat terbiasa dengan metode konvensional yaitu guru lebih aktif dalam proses pembelajaran di kelas sehingga siswa lebih banyak pasif. Hal ini sesuai dengan hasil penelitian oleh Nichen, dkk (2018, p. 74) yang menunjukkan bahwa dengan menerapkan model pembelajaran discovery learning pada tahap refleksi siklus I, ditemukan adanya kelemahan selama guru mengajar, yaitu siswa kurang memahami materi yang diajarkan oleh guru, siswa merasa malu dan takut untuk mengeluarkan ide dan gagasannya, serta siswa harus ditunjuk saat menyampaikan hasil diskusi kelompoknya. Dengan demikian kelemahan-kelemahan pada siklus I direfleksi dan diperbaiki pada siklus selanjutnya.

Sedangkan hasil observasi pada proses pelaksanaan siklus II aktivitas belajar siswa mengalami peningkatan dari siklus sebelumnya, dimana siswa mulai menunjukkan sikap antusias dalam belajar, siswa mulai merespon yang diberikan guru dengan memperhatikan penjelasan guru, memberi tanggapan pada kelompok lain, dan tidak malu dan takut untuk menyampaikan pendapatnya. Salah satu hal yang menarik bagi siswa dalam pembelajaran menggunakan model pemebelajaran discovery learning ini adalah aktivitas belajar siswa lebih aktif dalam mengidentifikasi masalah, saling bekerja sama, saling membantu dalam mengerjakan soal, dan berdiskusi sehingga dalam proses pembelajaran berjalan dengan baik dan efektif, sehingga hasil belajar siswa meningkat dan telah mencapai indikator keberhasilan yang ditentukan yaitu $80 \%$. Grafik kenaikan aktivitas belajar siswa dapat dilihat gambar 2 berikut ini. 


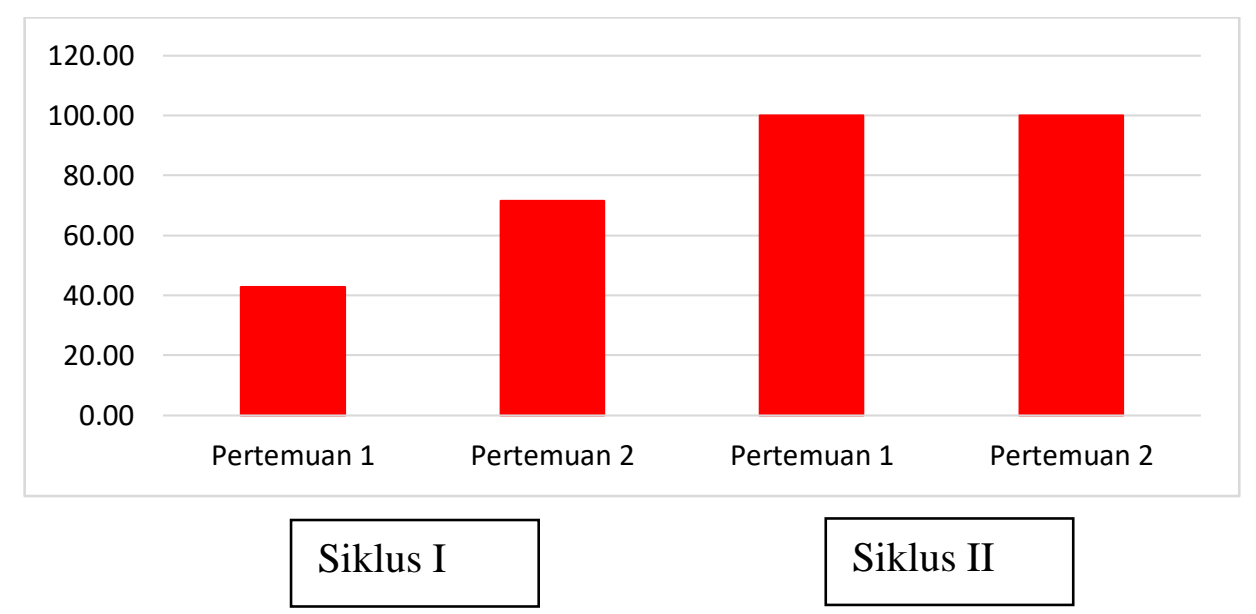

Gambar 1. Peningkatan aktivitas siswa

\section{Hasil Belajar}

Berdasarkan hasil evaluasi yang dilakukan oleh peneliti menunjukan bahwa pembelajaran dengan menerapkan model discovery learning terbukti efektif dalam meningkatkan hasil belajar siswa dan keterampilan berpikir kritis siswa (Amallia, dkk., 2017, p. 23). Sesuai dengan jurnal internasional (Balim, A., G., 2009, p. 1-20) yang menyatakan bahwa aktivitas dari penyelidikan dengan penemuan dapat digunakan dengan tujuan menggambarkan perhatian dari siswa dan keaktifan mereka untuk berpartisipasi lebih di kelas. Keberhasilan penerapan model pembelajaran discovery learning dalam meningkatkan hasil belajar siswa ditunjukan dengan adanya perubahan dalam proses siklus I ke siklus II pada tema daerah tempat tinggalku di kelas IV SD Negeri 5 Pasir Putih. Peningkatan hasil belajar siswa pada siklus I dan siklus II, ditunjukkan pada gambar 3 berikut:

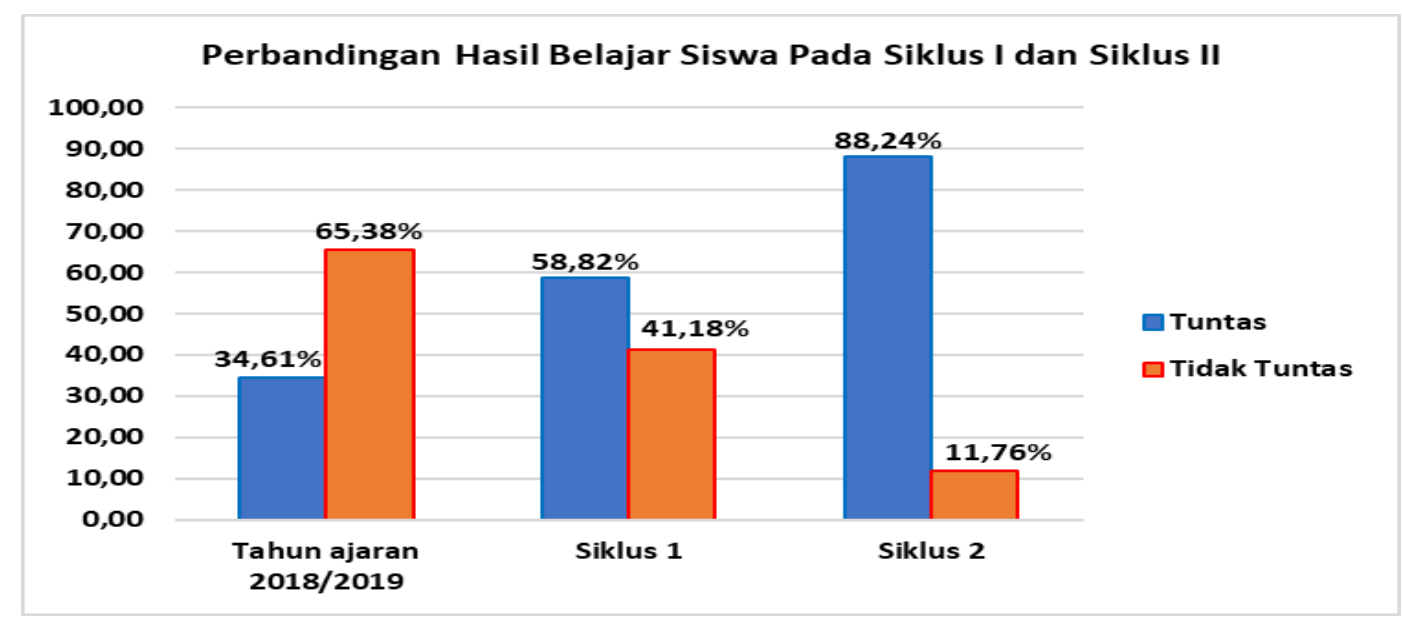

Gambar 3. Grafik Perbandingan Peningkatan Hasil Belajar Siswa Siklus I dan Siklus II

Gambar 3 menunjukan bahwa hasil belajar siswa pada siklus I sudah meningkat dari tahun ajaran sebelumnya namun belum mencapai indikator kinerja dalam penelitian ini. Pada siklus I siswa mencapai ketuntasan belajar sebesar 7 orang atau $41,14 \%$ dan persentase tidak tuntas sebesar 10 orang atau 58,82\% dengan nilai rata-rata 57,61. Maka, hasil belajar siswa belum mencapai indikator ketuntasan. Hal ini disebabkan oleh beberapa aspek yang ditemukan pada saat proses pembelajaran berlangsung, yaitu ada sebagian siswa kurang memperhatikan guru dan asik bermain sehingga terjadi keributan, adapula sebagian siswa yang merasa malu-malu saat mengemukakan pendapatnya serta guru yang belum memaksimalkan pembelajaran dengan langkah-langkah rancangan menggunakan model pembelajaran discovery learning, hal ini berarti 
bahwa pembelajaran pada siklus I belum dikatakan efektif, karena belum terjadi perubahan atau peningkatan pada aspek kognitif dari dalam diri siswa. Sejalan dengan pendapat Bloom dalam Sudjana (2016, p. 15) bahwa pembelajaran belum dikatakan efektif atau tercapai jika tidak ada perubahan pada aspek kognitif, efektif, dan psikomotor. Dengan demikian, maka dilakukannya refleksi dan perbaikan untuk dilaksanakan pada siklus berikutnya yaitu ke siklus II.

Selanjutnya dilakukan pelaksanaan tindakan siklus II dan hasil belajar siswa terjadi peningkatan dibandingkan pada siklus I. Peningkatan hasil belajar siswa pada siklus II dikarenakan selama siklus II, guru telah melakukan perbaikan dan penyesuaian dengan skenario model pembelajaran discovery learning seperti guru yang telah memaksimalkan penyampaian motivasi kepada siswa, guru merangsang siswa untuk mengumpulkan ide dan gagasan dari berbagai informasi dalam LKS yang disediakan, serta guru memberi penguatan kepada siswa dalam mempresentasikan hasil pendapatnya. Untuk meningkatkan keterampilan mengkomunikasi dan penguasaan konsep yang dilatihkan melalui model pembelajaran yang tepat akan menghantarkan siswa pada pembelajaran yang lebih bermakna (Arika, 2015, p. 7). Dengan hal tersebut maka siswa mulai menunjukkan sikap antusias dalam belajar. Hal ini sesuai dengan pendapat Slameto bahwa semakin tinggi antusias belajar siswa maka kemungkinan untuk mencapai prestasi yang tinggi juga akan semakin besar, begitupun sebaliknya (Ahmad Sulu, 2017, p. 109). Dengan melihat hasil belajar siswa yang telah mencapai Kriteria Kentuntasan Minimal (KKM) yang ditetapkan oleh SDN 5 Pasir Putih Kabupaten Muna yaitu 65, maka penerapan model pembelajaran discovery learning pada tema daerah tempat tiggalku di kelas IV mengalami peninglatan karena telah mencapai indikator keberhasilan yaitu $80 \%$.

\section{Simpulan}

Berdasarkan hasil analisis data pada penelitian dan pembahasan yang telah diuraikan, dapat disimpulkan bahwa penerapan model pembelajaran discovery learning dapat meningkatkan hasil belajar siswa tema daerah tempat tinggalku di kelas IV SDN 5 Pasir Putih. Peningkatan ini bisa dilihat mulai dari siklus I hingga siklus II yang ditunjukkan yakni pada siklus I dengan ratarata 62,75 yaitu dari 17 orang siswa, yang tuntas sebanyak 7 orang dengan persentase $41,18 \%$ dan yang tidak tuntas sebanyak 10 orang dengan persentase $58,82 \%$. Sedangkan pada siklus II diperoleh peningkatan dengan rata-rata 82,35 yang tuntas sebanyak 15 orang dengan persentase $88,24 \%$ dan yang tidak tuntas sebanyak 2 orang dengan persentase $11,76 \%$. Oleh karena itu, pada siklus II telah mencapai indikator keberhasilan sebesar $80 \%$ maka hasil belajar siswa pada penelitian ini meningkat.

\section{Daftar Pustaka}

Ahmad, Sulu, dkk, 2017, 'Antusiasme Belajar Siswa Kelas X Ilmu Pengetahuan Bahasa, Jurnal Pelita Pendidikan, vol. 5, no. 1, hh. 108-117. Rertrieved from https://jurnal.unimed.ac.id/2012/index.php/pelita/article/download/8451/7060

Amallia, dkk. 2017, 'Penerapan Model Pembelajaran Discovery Learning Untuk Meningkatkan Kemampuan Berpikir Kritis Dan Hasil Belajar Kimia. Jurnal Pendidikan Kimia Indonesia, vol. 1, no. 1, hh. 23-29. http://dx.doi.org/10.23887/jpk.v1i1.12808

Arika, 2015, 'Application Discovery Learning Model To Improve Physics Students Process Skill. Jurnal Pendidikan Fisika FKIP Universiats Riau, Vol. 1, no. 1, hh. 1-10. https://media.neliti.com/media/publications/199205-penerapan-model-pembelajarandiscovery-1.pdf

Balim, A., G. 2009. The Effect of Discovery Learning onStudents' Success and Inquiry Learning Skill. Egitim Arastirmarali-Eurasian Jurnal of Educational Research. Spring (35). 1-20. https://www.google.com/url?sa=t\&rct=j\&q=\&esrc=s\&source=web\&cd=\&cad=rja\&uact $=$ $\underline{8 \& v e d=2 \text { ahUKEwilgIah7pbrAhWRbysKHdLiDz0QFjAAegQIAxAB\&url=http\%3A\%2F }}$ \%2Fpdfs.semanticscholar.org\%2Fc92b\%2Ff85fbf5545de25f1724f22f948436f107d80.pdf 


\section{\%26ved\%3D2ahUKEwirRzMrscjeAhWov1MKHc3VCZMQFjADegQIAxA\%26usg\%3} DAOvVaw1yO7mu8QTR3lzXnqsZAu8O\&usg=AOvVaw0OcEtuokUvml7R0qsnZkWS

Kawuri, M. Y. R. T., Ishafit, I., \& Fayanto, S., 2019, 'Efforts to improve the learning activity and learning outcomes of physics students with using a problem-based learning model. IJIS Edu: Indonesian Journal of Integrated Science Education, vol. 1, no. 2, hh. 105-114. Rertrieved from https://ejournal.iainbengkulu.ac.id/index.php/ijisedu/article/view/1957

Narmaditya, B. S., Winarning, W., \& Wulandari, D., 2017, 'Impact of problem-based learning on student achievement in economics course', Classroom Action Research Journal (CARJO), vol. 1, no. 1, hh. 1-11. Rertrieved from https://www.academia.edu/download/63390759/9919-31128-1-PB20200521-1185391npa4hu.pdf

Nichen, dkk., 2018, Penerapan Model Pembelajaran Discovery Learning Untuk Meningkatkan Kemampuan Berpikir Kreatif dan Hasil Belajar Siswa. Perspektif Ilmu Pendidikan, vol. 32. No.1, hh. 69-77. Rertrieved from https://doi.org/10.21009/PIP.321.8

Rahayu, I. P., dkk, 2019, 'Penerapan Model Discovery Learning untuk Meningkatkan Keaktifan dan Hasil Belajar Tematik', Journal Of Education Action Research, vol. 3, no. 3, hh. 193200.https://www.google.com/url?sa=t\&rct=j\&q=\&esrc=s\&source=web\&cd=\&cad=rja\&u act=8\&ved=2ahUKEwitwO6185DrAhV28HMBHTywBgEQFjAAegQIAhAB\&url=https $\% 3 \mathrm{~A} \% 2 \mathrm{~F} \% 2 \mathrm{Fejournal} . u n d i k s h a . a c . i d \% 2$ Findex.php\%2FJEAR\%2Farticle\%2Fdownload $\% 2 F 17369 \% 2 F 10443 \& u s g=A O v V a w 0 y 001 R w C M 6 H p 4 M 0 e i Y a 2 T W$

Slameto, 2010, Belajar dan Faktor-faktor yang Mempengaruhi, Rineka Cipta, Jakarta.

Sofyan, H., \& Komariah, K., 2016, 'Pembelajaran problem bassed learning dalam implementasi kurikulum 2013 Di SMK', Jurnal Pendidikan Vokasi, vol. 6, no. 3, hh. 260-271. https://www.google.com/url?sa=t\&rct=j\&q=\&esrc=s\&source=web\&cd=\&cad=rja\&uact= 8\&ved=2ahUKEwjimYHJ9JDrAhUlg-

YKHWX9D2EQFjABegQIAhAB\&url=https\%3A\%2F\%2Fjournal.uny.ac.id\%2Findex.ph p\%2Fjpv\%2Farticle\%2FviewFile\%2F11275\%2F8744\&usg=AOvVaw3tvfO5sBKH6weY Gk5A1c_U

Sudjana, Nana, 2016, Penilaian Hasil Proses belajar Mangajar (cetakan ke-20), PT. Remaja Rosda Karya, Bandung.

Suprijiono, A. (2017). Cooperative Learning Teori \& Aplikasi Paikem (XVII). Yogyakarta: Pustaka Pelajar. 